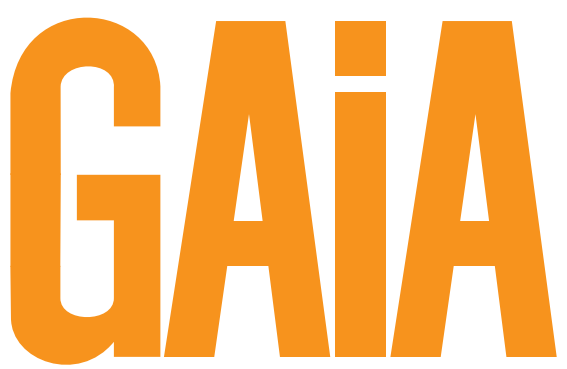
3 | 2016
ÖKOLOGISCHE PERSPEKTIVEN FÜR WISSENSCHAFT UND GESELLSCHAFT

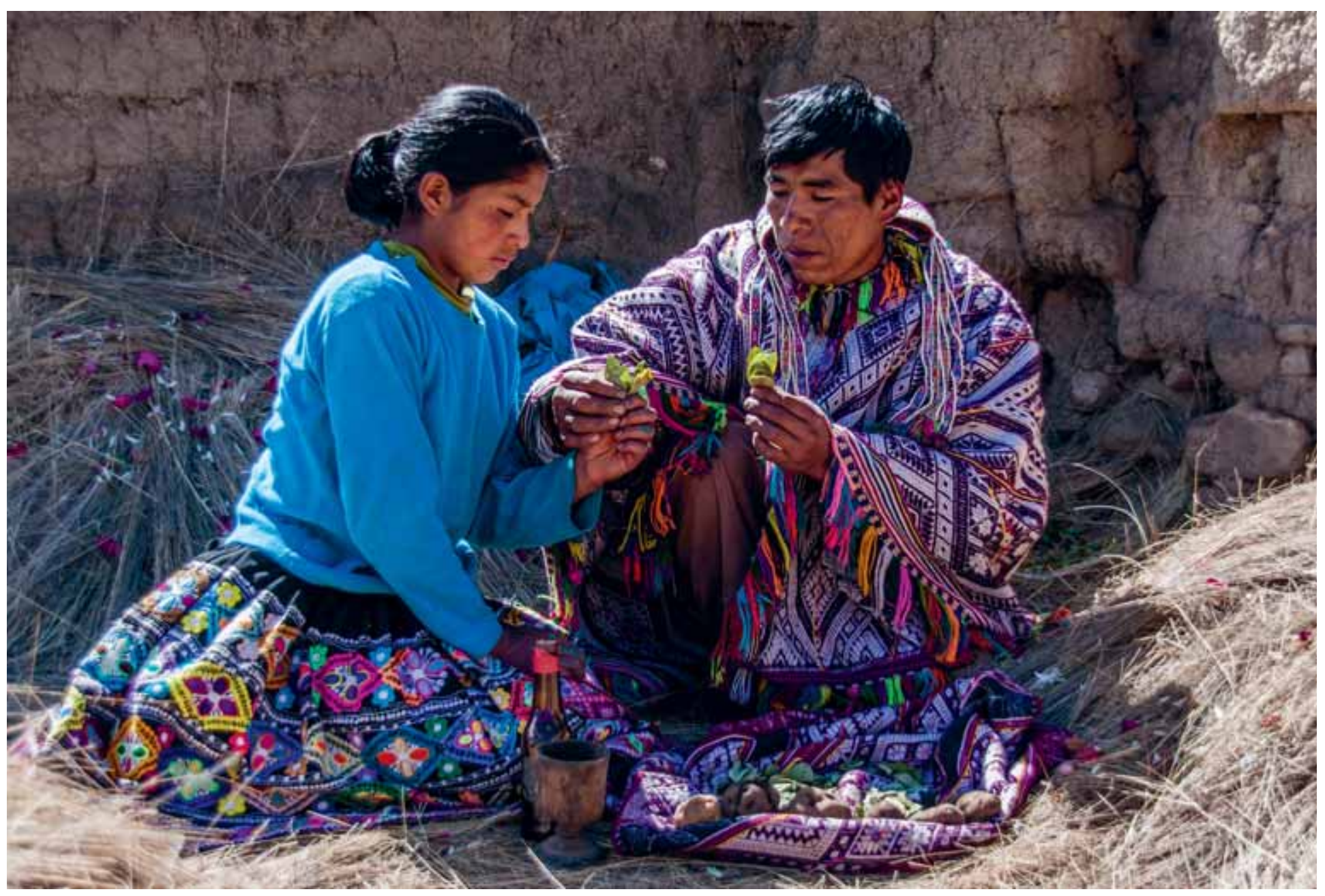

- CULTURAL VALUES AND CLIMATE CHANGE

ECONOMIC VALUATION OF ECOSYSTEM SERVICES

EXEMPLARY TRANSDISCIPLINARY PROJECTS

\footnotetext{
1 Dekom GAIA is available online at www.ingentaconnect.com/content/oekom/gaia

verlag CAIAEA 25/3,145-224(2016)
} 


\section{Promoting Sanitation in South Africa through Nutrient Recovery from Urine}

The water utility of Durban, eThekwini Water and Sanitation (EWS), installed urine-diverting dry toilets to provide sanitation to under-served communities in rural and peri-urban areas. While faeces was treated by dehydration, urine was discharged into a soak away in the ground. EWS teamed up with the Swiss Federal Institute of Aquatic Science and Technology (Eawag) and other partners in Switzerland and

Kai M. Udert, Bastian Etter, South Africa to valorise this resource. The VUNA project developed a sanitation system Teddy Gounden which produces a valuable fertiliser from urine, reduces pollution of water resources and promotes the acceptance of dry toilets.

Promoting Sanitation in South Africa through Nutrient Recovery from Urine | GAIA 25/3 (2016): 194-196

Keywords: fertiliser, nutrient recovery, source separation, urine diversion

\section{Tackling the Sanitation Problem ...}

South Africa faces a number of pressing sanitation challenges. As part of an overall sanitation strategy the local water utility of Durban, eThekwini Water and Sanitation (EWS), introduced urinediverting dry toilets (UDDTs) to several peri-urban and rural communities, which did not have any or only inadequate sanitation previously. UDDTs were chosen, because providing sewer-based sanitation would have been prohibitively expensive and impractical due to the hilly landscape and water scarcity (Gounden et al. 2006).

In UDDTs, urine and faeces are separated to facilitate the drying of the faeces. During dehydration, most of the pathogens are killed, the malodour is gone and the volume is significantly reduced. The urine, however, is usually not treated but instead directly infiltrated into the ground. This was also the case for the UDDTs in the Durban area. Urine infiltration can lead to environmental pollution, such as eutrophication, and valuable resources are lost: urine contains most of the excreted nutrients, especially nitrogen,potassiumand phosphorus. They can be used as fertiliser, if they could be recovered from urine (Udert et al. 2006).

Contact: Dr. Kai M. Udert | Tel.: +41587655360 | E-Mail: kai.udert@eawag.ch Bastian Etter | E-Mail: bastian.etter@eawag.ch both: Swiss Federal Institute of Aquatic Science and Technology (Eawag) | Überlandstr. 133 | 8600 Dübendorf | Switzerland

Teddy Gounden | eThekwini Water and Sanitation | Strategic Executive | Durban | South Africa | E-Mail: teddygo@dmws.durban.gov.za

(C) 2016 K. M. Udert et al.; licensee oekom verlag. This is an Open Access article distributed under the terms of the Creative Commons Attribution License (http://creativecommons.org/licenses/by/3.0), which permits unrestricted use, distribution, and reproduction in any medium, provided the original work is properly cited.

\section{... with an International Team ...}

Although EWS identified UDDTs as the most suitable sanitation system for large parts of the municipality, the acceptance of the toilets within the community was low. Furthermore, the environmental pollution of urine could become a serious problem, if the infiltration of urine were to be continued. Through support from the Bill and Melinda Gates Foundation, EWS teamed up with the Swiss Federal Institute of Aquatic Science and Technology (Eawag) to develop an improved sanitation system based on nutrient recovery from urine (Etter et al. 2015). Eawag was chosen because it has a long-standing record of research on urine separation.

The project was given the name VUNA, which means "harvest" in the isiZulu language or Valorisation of Urine Nutrients in Africa. According to the name, the project had three basic objectives:

- promote the use of UDDTs by giving urine a value;

- produce a valuable fertiliser by closing the nutrient cycle;

- protect the environment by reducing pollution.

Besides Eawag, several other academic institutions contributed to the project. The technologies for urine treatment were developed and tested by the Pollution Research Group (PRG) at the University of KwaZulu-Natal(UKZN) and Eawag. The Environmental Chemistry Laboratory (LCE) at the Swiss Federal Institute of Technology in Lausanne(EPFL) investigated the pathogens present in urine and their inactivation during treatment, while Eawag undertook research on pharmaceutical residues. The fertiliser value of the urine treatment products was tested by the Plant Nutrition Group at the Swiss Federal Institute of Technology in Zurich (ETHZ), and the School of Agricultural, Earth and Environmental Sciences at UKZN. Studies on the current acceptance of the toilets and how it may be improved were conducted by the 
School of Nursing and Public Health of UKZN. The economics of urine collection and treatment were studied by the Centre for Development and Cooperation (NADEL) at ETHZ and by Eawag.

\section{... in a Transdisciplinary Research Effort}

Sanitation, the management and disposal of human excreta, includes many technical and scientific aspects. Technologies have to be chosen which prevent diseases, protect the environment and conserve valuable resources. In order to consider these aspects adequately, environmental engineers, chemists, biologists and agronomists worked together in the VUNA project. However, sanitation is not only a technical challenge, it is a central function of any human society. To be successful, a sanitation system must be economically viable and able to be supported by the incumbent political administration. Furthermore, the needs and attitudes of the citizens have to be considered. Such aspects were investigated by business economists and social scientists within the VUNA team. By including researchers from diverse disciplines such as environmental engineering, chemistry, biology, agronomy, business economics, sociology and public health, VUNA was a truly transdisciplinary research project. Moreover, VUNA also set an example as a project which builds bridges between research and practice by combining the expertise from academia and a public water utility, that is, EWS. Last but not least, the project established new links between researchers and utilities in Switzerland and South Africa.

\section{What We Have Done}

\section{Converting Waste into a Valuable Fertiliser}

Urine has to be treated in order to recover nutrients in a useable form and to prevent nuisance from malodour and environmental pollution. In the VUNA project, we investigated three processes for urine treatment: struvite precipitation, a combination of nitrification and distillation, and electrolysis (Udert et al. 2015). All three processes achieve different goals. Struvite precipitation is basically a process to recover phosphorus in a solid form (Grau et al. 2015). The combination of nitrification and distillation is a more complex process than struvite precipitation, but it is a comprehensive treatment of urine. The final product is a pasteurised and highly concentrated liquid containing nearly all nutrients (Fumasoli et al. 2016). The only by-products are distilled water and small amounts of sludge. While nitrification/distillation and struvite precipitation were tested in prototype plants, electrolysis was investigated in the laboratory only (Zöllig 2015). This process can be used to remove ammonia and organic substances. According-

\footnotetext{
1 Another manuscript is in preparation for Environmental Science Q Technology by B.D. Oezel Duygan, K. M. Udert, A. Remmele, C. S. McArdell under the title Fate of Pharmaceuticals in Source-separated Urine during Storage,
} Biological Treatment and Powdered Activated Carbon Adsorption. ly, its primary goal is not nutrient recovery but malodour elimination and prevention of environmental pollution.

\section{Nutrients and Contaminants}

Pot trials with isotope marked fertilisers revealed that struvite and nitrified urine result in similar nutrient uptake rates as potassium dihydrogen phosphate $\left(\mathrm{KH}_{2} \mathrm{PO}_{4}\right)$ and ammonium nitrate $\left(\mathrm{NH}_{4} \mathrm{NO}_{3}\right)$, respectively (Bonvin et al. 2015). However, analysis of urine samples taken in Durban showed that the urine also contains considerable numbers of pathogens and high concentrations of residues of pharmaceuticals such as antibiotics and antiretroviral drugs (Bischel et al. 2015 a). Through laboratory testing we determined that pathogens and pharmaceutical residues were only partially removed during the nitrification process (Bischel et al. $2015 b)^{1}$. However, pathogens are effectively killed during the following distillation step, when the solution is heated to $80^{\circ} \mathrm{C}$ for several hours. When it comes to pharmaceutical residues, laboratory experiments have shown that they can be effectively removed with activated carbon adsorption in an additional treatment step.

\section{Collect, Buy and Sell}

A urine collection scheme was established in Durban to provide urine to the laboratory and pilot scale tests for urine treatment and to investigate and improve urine collection itself. The data was used to establish a computer model, which allows modelling and optimising of urine collection (Rossboth 2013). With the help of additional field data and computer calculations, a business model for the urine management was established (Etter 2014). Our studies showed that collection costs can be more than halved with optimised collection strategies. Any cost calculations, however, also haveto consider indirect benefits, such as the provision of hygienic sanitary installations, dignity, reduction in environmental pollution and the creation of jobs. In an in-depth study on financial incentives (Tilley 2016), toilet users received financial compensation for any urine they brought to a central collection point. The study showed that providing such incentives can be expensive, but it increases the urine production and fosters the use of the UDDTs.

\section{It's the Users' Decision}

The successful implementation of a new sanitation concept requires respect for the personal needs and the cultural background of the population. Surveys in 2011 (Roma et al. 2013) and 2014 (Etter et al. 2015), revealed that the fraction of the respondents, who were content or very content with the system was rather low but had increased from 30 to 40 percent. The main complaints related to construction flaws (e. g., defective doors), malodour or the need to empty the dried faeces from the vaults. Many of the respondents viewed UDDTs as an intermediate solution before flushing toilets would be provided. EWS used these results to develop educational campaigns on hygiene and sanitation. Presentation in schools, focus discussion and educational material such as brochures, posters and videos were developed to inform residents about the background and the goals of the chosen sanitation system. While proper information is generally considered to be essen- 
tial for the introduction of a new sanitation system, the success of these campaigns will have to be evaluated in a few years' time.

\section{The Way Forward}

With the VUNA project we were able to show that urine does not have to be a waste stream full of pollutants, but can be transformed into a safe and valuable product. By this, the project was an important step forward for the acceptance of sanitation systems based on source separation. So far, UDDTs have mainly been installed to simplify treatment of faeces. Urine valorisation is another important stimulant for implementing a sanitation system based on the separate collection of faeces and urine.

The VUNA project triggered other research studies, especially on the treatment of urine. However, the impact on the practical implementation of urine source separation has also been remarkable. By operating pilot reactors and managing urine collection systems in the field, VUNA helped to get more practitioners interested in urine source separation and the valorisation of nutrients from urine. For example, a urine nitrification reactor is currently in operation in Nairobi/Kenya to treat urine collected by the organisation Sanergy. Our studies have shown that reliable and efficient urine collection is a key to successfully implementing a sanitation system based on urine separation. In peri-urban and rural areas, collection routes have to be optimised, otherwise, so that costs are not prohibitively high. However, in large buildings or dense neighbourhoods, including informal settlements, distances between sources of urine are small and thus collection costs will be low. Such locations will be the best for implementing urine separation projects in the near future. ${ }^{2}$ Besides the scientific knowledge and practical experiences, we also obtained a license for the fertiliser produced in the nitrification/distillation process. It is a temporary license until February 2018 issued by the Swiss Federal Office of Agriculture. An extension is foreseen, if we can prove that pharmaceutical residues can be removed effectively. Current studies on using activated carbon show that this is possible.

We thank the funding agents for the financial support and advice. The Bill \& Melinda Gates Foundation initiated the project and provided the majority of the funding (OPP1011603). Further funding was provided by the Swiss National Science Foundation, the United States National Science Foundation and the project partners. We also express our gratitude to all researchers and coworkers in the field, laboratory, and office for their support and commitment.

\section{References}

Bischel, H. N., B. D. Özel Duygan, L. Strande, C. S. McArdell, K. M. Udert, T. Kohn. 2015 a. Pathogens and pharmaceuticals in source-separated urine in eThekwini, South Africa. Water Research 85: 57-65.

Bischel, H. N., A. Schertenleib, A. Fumasoli, K. M. Udert, T. Kohn. 2015 b. Inactivation kinetics and mechanisms of viral and bacterial pathogen surrogates during urine nitrification. Environmental Science: Water Research Q Technology 1/1: 65-76.

2 For further information see Etter et al. (2015) and www.eawag.ch/vuna.
Bonvin, C. et al. 2015. Plant uptake of phosphorus and nitrogen recycled from synthetic source-separated urine. Ambio 44/Suppl. 2: S217-S227.

Etter, L. 2014. Business-Modell für urinbasierten Dünger. Master's thesis, University St. Gallen, Switzerland.

Etter, B., K. M. Udert, T. Gounden (Eds.). 2015. Valorisation of urine nutrients: Promoting sanitation a nutrient recovery through urine separation. Final report. Dübendorf, Switzerland: Swiss Federal Institute of Aquatic Science and Technology (Eawag).

Fumasoli, A., B. Etter, B. Sterkele, E. Morgenroth, K. M. Udert. 2016. Operating a pilot-scale nitrification/distillation plant for complete nutrient recovery from urine. Water Science and Technology 73/1: 215-222.

Gounden, T., B. Pfaff, N. MacLeod, C. Buckley. 2006. Provision of free sustainable basic sanitation: The Durban experience. $32^{\text {nd }}$ WEDC Conference, Sustainable Development of Water Resources, Water Supply and Environmental Sanitation. Colombo, Sri Lanka, November. http://wedc.lboro.ac.uk/ resources/conference/32/Gounden.pdf (accessed September 7, 2016).

Grau, M. G. P., S. L. Rhoton, C. J. Brouckaert, C. A. Buckley. 2015. Evaluation of an automated struvite reactor to recover phosphorus from source-separated urine collected at urine diversion toilets in eThekwini. Water SA 41/3: 383-389.

Roma, E., K. Philp, C. A. Buckley, S. Xulu, D. Scott. 2013. User perceptions of urine diversion dehydration toilets: Experiences from a cross-sectional study in eThekwini Municipality. Water SA 39/2: 305-312.

Rossboth, T. 2013. Model-based systems analysis of the collection management of source-separated urine in eThekwini Municipality/South Africa. Master's thesis, University of Natural Resources \& Life Sciences (BOKU), Vienna, Austria.

Tilley, E. 2016. Cost-effectiveness and community impacts of two urinecollection programs in rural South Africa. Environmental Science: Water Research a Technology 2/2: 320-335.

Udert, K. M. et al. 2015. Technologies for the treatment of source-separated urine in the eThekwini Municipality. Water SA 41/2: 212-221.

Udert, K. M., T. A. Larsen, W. Gujer. 2006. Fate of major compounds in sourceseparated urine. Water Science and Technology 54/11-12: 413-420.

Zöllig, H. 2015. Electrolysis for the treatment of stored source-separated urine. PhD thesis 22854, Swiss Federal Institute of Technology, ETH, Zurich, Switzerland.

Submitted May 27, 2016; revised version accepted September 14, 2016.

Kai M.Udert

Born 1971 in Chur, Switzerland. 2002 PhD. Currently leader of the research group on decentralised wastewater treatment and source separation at the Swiss Federal Institute of Aquatic Science and Technology (Eawag), Dübendorf, Switzerland. 2010 to 2015 Swiss principal investigator of the project Valorisation of Urine Nutrients in Africa (VUNA). Research interests: new technologies for resource recovery from wastewater, source separation, on-site wastewater treatment.

\section{Bastian Etter}

Born 1983 in Biel, Switzerland. 2009 MSc Environmental Engineering. 2008 to 2010 project collaborator Struvite from Urine in Nepal (STUN). 2010 to 2015 coordinator of the project Valorisation of Urine Nutrients in Africa (VUNA) in South Africa and Switzerland. Since 2016 coordinator of NEST WaterHub, Dübendorf, Switzerland. Research interests: resourceoriented sanitation, decentralized wastewater treatment.

Teddy Gounden

Born 1958 in Durban, South Africa. 2001 Bachelor of Commerce. Currently strategic executive with eThekwini Water and Sanitation (EWS), Durban. 2010 to 2015 South African principal investigator of the project Valorisation of Urine Nutrients in Africa (VUNA). Area of expertise: nutrient recovery
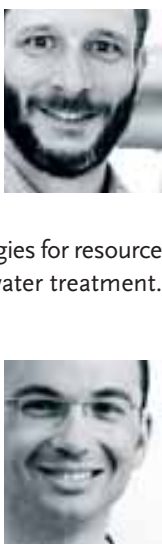
from source-separated sanitation systems, water reuse, community development. 